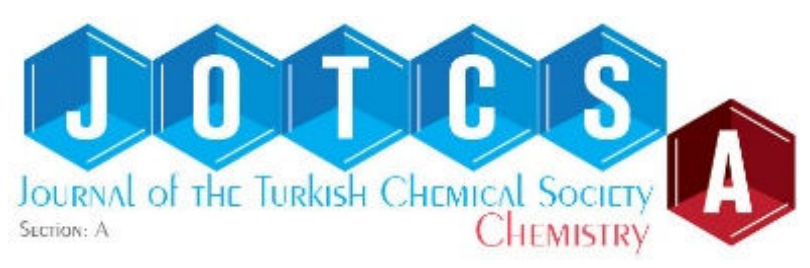

(This article was presented to the 28th National Chemistry Congress and submitted to JOTCSA as a full manuscript)

\title{
Antiproliferative effect of Cherry laurel
}

\author{
Ali Aydın*1, Ramazan Erenler ${ }^{2}$, Bülent Yılmaz², Şaban Tekin ${ }^{1}$ \\ ${ }^{1}$ Faculty of Art and Science, Department of Molecular Biology and Genetics, \\ Gaziosmanpaşa University, 60240, Tokat, Turkey \\ 2 Faculty of Art and Science, Department of Chemistry, Gaziosmanpaşa University, \\ 60240, Tokat, Turkey
}

\begin{abstract}
Cherry laurel (Prunus laurocerasus) fruits including phenolic and flavonoid contents are consumed as fresh, dried or prepared in marmalade and its leaves containing cyanogenic glycosides have healing activity of a well-known Anatolian folkloric remedy. Herein, Cherry laurel fruits were boiled in water for $2 \mathrm{~h}$, then extracted with hexane, EtOAc, and $\mathrm{BuOH}$ successively. Antiproliferative activities of extracts were evaluated on HeLa (Human Cervix Carcinoma), HT29 (Human Colorectal Adenocarcinoma), C6 (Rat Brain Tumor Cells), and Vero (African Green Monkey Kidney) cell lines. All extracts exhibited slightly antiproliferative effects on various cancer cell lines at high concentration. We assessed the ability of extracts of cherry laurel fruit to devastate the membrane of cells. Results indicated that cherry laurel fruit extracts slightly destroys the cellular membrane in tumor cell lines at merely high concentrations. The results of this study does not support the efficacy of cherry laurel fruit extracts as an anticancer agent for cancer cells, but it suggests that cherry laurel fruit extracts may be used through reducing cytotoxicity, a potential adjuvant therapy to current chemotherapeutic agents. Fatty acids of hexane extract were also determined by GC-MS analysis and found out that linoleic acid, palmitic acid, and oleic acid were the major products.
\end{abstract}

Keywords: Cherry laurel; laetrile; anticancer activity; cytotoxic activity

Submitted: July 4, 2016. Revised: August 22, 2016. Accepted: August 29, 2016.

Cite This: Aydın A, Erenler R, Yılmaz B, Tekin Ş. Antiproliferative effect of Cherry laurel. JOTCSA. 2016;3(3):217-28.

DOI: $10.18596 /$ jotcsa.21204.

*Corresponding author. E-mail: aliaydin.bio@gmail.com; ali.aydin4409@gop.edu.tr,Tel:

+90-356-2521616, Fax: +90-356-2521585. 
Aydın, Erenler, Yılmaz, and Tekin, JOTCSA. 2016; 3(3): 217-228. RESEARCH ARTICLE

\section{INTRODUCTION}

Plants have been used for treatment of various diseases from ancient times. Drug discovery and development process from natural products for confronting cancer has taken in the reasonable opportunity to achieve most new clinical applications of plant secondary metabolites and their derivatives (1, 2). Cancer, occurring from heterogeneous diseases, is an excruciating illness and constitutes a significant medical problem. Despite promising progress in cancer epidemiology, cancer treatments are still not a good medicine without serious side effects, persistent drug resistance, and limited effect due to their ADME properties. Because of the need for more effective anticancer agents, natural products can be considered as suitable anticancer drug candidates. The natural products acquiring significance in the treatment of malady have contributed to health care worldwide through the isolation of bioactive compounds. Nearly $60 \%$ of drugs approved for cancer treatment are of natural source represent more than $50 \%$ of all the drugs in clinical use of the world $(3,4)$. Several of them, namely taxol, camptothecin, and etoposide, are in clinical use all over the world. Many cancer research studies have been currently performed using extracts or isolate from plants in an effort to discover new therapeutic agents. Prunus laurocerasus (cherry laurel) is an evergreen species of cherry (Prunus), a shrub, which grows in southwestern Asia, and the Balkans. Ethanolic extraction of the fresh leaves of cherry laurel has a long traditional use as a homeopathic mother tincture. In Anatolian folk medicine, the leave extract is used in the therapy of coughs, hemorrhoids, eczemas, asthma, digestive system complaints as well as in the treatment of stomach ulcers (5-13). Traditionally it is also used in analgesic, antispasmodic, and sedative effects and furthermore, according to latest research, its aqueous and ethanolic extracts showed antifungal, antinociceptive and antiinflammatory activity without inducing any gastric lesions (5-13). Overall, leaves, fruit, and seed of cherry laurel are a valuable herbal medicine and used for various health complaints. However, cherry laurel containing cyanogenic glycosides and amygdalin (Laetrile) can be toxic due to using dosage. According to our knowledge, there are no literature data on fruit of cherry laurel biological activities, especially the antiproliferative effect, to date. The topic of this study was to assess pharmacological activity, cell cytotoxicity, and morphological alteration of valuable extracts from cherry laurel used traditionally in Anatolia. The antiproliferative activity of the extracts was conducted following the European Pharmacopoeia 8.0 protocol. According to this protocol, we investigated the antiproliferative and cytotoxic activity of fruits of cherry laurel in various solvent systems. Aqueous (WEPL), hexane (HEPL), n-butanol (NBEPL) and ethyl acetate (EAEPL) extracts of cherry laurel (25 to $500 \mu \mathrm{g} / \mathrm{mL}$ ) were investigated for their antiproliferative and cytotoxic activity against HT29, HeLa and C6 cancer cells and nontumorigenic Vero cells 
Aydın, Erenler, Yılmaz, and Tekin, JOTCSA. 2016; 3(3): 217-228. RESEARCH ARTICLE

using ELISA BrdU Cell Proliferation assay and LDH cytotoxicity assay as well as morphological analysis.

\section{MATERIALS and METHODS}

\section{Extraction}

Cherry laurel fruits were boiled in water for $2 \mathrm{~h}$ then extracted with hexane, EtOAc, and n-butanol. After filtration and evaporation process, water, hexane, ethyl acetate, and nbutanol extracts were acquired to execute the antiproliferative activities (Table 1).

Table 1. Cherry laurel fruits extracts.

\begin{tabular}{ll}
\hline Solvent system & Fruits \\
\hline Water & WEPL \\
Hexane & $H E P L$ \\
EtOAc & EAPL \\
$n$-butanol & $N B E P L$ \\
\hline
\end{tabular}

\section{Preparation of cell culture}

The anticancer potential of cherry laurel extracts was investigated on cancerous HT29 (ATCC ${ }^{\circledR}$ HTB-38 ${ }^{\mathrm{TM}}$ ), HeLa (ATCC ${ }^{\circledR} \mathrm{CCL}^{-2}{ }^{\mathrm{TM}}$ ), and $\mathrm{C} 6$ cells $\left(\right.$ ATCC $^{\circledR} \mathrm{CCL}^{-107^{\mathrm{TM}}}$ ) and nontumorigenic Vero cells $\left(\mathrm{ATCC}^{\circledR} \mathrm{CCL}-81^{\mathrm{TM}}\right.$ ). The cell lines were cultured in a cell medium (Dulbecco's modified eagle's) enriched with $10 \%(\mathrm{v} / \mathrm{v})$ fetal bovine serum and $2 \%(\mathrm{v} / \mathrm{v})$ Penicillin-Streptomycin $(10,000 \mathrm{U} / \mathrm{mL})$. First, old medium was removed out of the flask while cells had reached approximately $80 \%$ confluence. Next, cells were taken from the flasks surface using 4-5 $\mathrm{mL}$ of trypsin-EDTA solution and then subjected to centrifugation. Following, the cell pellet was suspended with $4 \mathrm{~mL}$ of DMEM working solution and was counted to obtain a final concentration of $5 \times 10^{4}$ cells $/ \mathrm{mL}$, and inoculated into wells ( $100 \mu \mathrm{L}$ cells/well).

\section{Cell proliferation assay (CPA)}

A cell suspension containing approximately $5 \times 10^{3}$ cells in $100 \mu \mathrm{L}$ was seeded into the wells of 96-well culture plates. The cells were treated with cherry laurel extracts and control drug, 5-fluorouracil (5FU), dissolved in sterile DMSO ( $\max 0.5 \%$ of DMSO) at final concentrations of $25,50,100,150,200,250,375$, and $500 \mu \mathrm{g} / \mathrm{mL}$ at $37^{\circ} \mathrm{C}$ with $5 \% \mathrm{CO}_{2}$ overnight. The final volume of the wells was set to $200 \mu \mathrm{L}$ by medium. Cell proliferation assay was evaluated by ELISA BrdU methods as described previously (14).

\section{Calculation of $\mathrm{IC}_{50}$ and $\%$ inhibition}

IC $_{50}$ value is a concentration that inhibits half of the cells in vitro. The half maximal inhibitory concentration ( $\mathrm{IC}_{50}$ ) of the test and control compounds was calculated using XLfit5 or excel spreadsheet and represent in $\mu \mathrm{M}$ at $95 \%$ confidence intervals. The 
Aydın, Erenler, Yılmaz, and Tekin, JOTCSA. 2016; 3(3): 217-228. RESEARCH ARTICLE

proliferation assay results were expressed as the percent inhibition according to the following formula:

$$
\text { Inhibition }(\%)=1-\left(\frac{\text { Absorbance of Treatments }}{\text { Absorbance of DMSO }}\right) \times 100
$$

\section{Cytotoxic activity assay}

The cytotoxicity of the compounds and of 5 fluorouracil on HeLa, C6, HT29, and Vero cells was determined through a Lactate Dehydrogenase Assay Kit according to the manufacturer's instructions. Approximately $5 \times 10^{3}$ cells in $100 \mu \mathrm{L}$ were placed into 96well plates as triplicate and treated with $\mathrm{IC}_{50}(\mu \mathrm{g} / \mathrm{mL})$ concentrations of test compounds at $37^{\circ} \mathrm{C}$ with $5 \% \mathrm{CO}_{2}$ for $24 \mathrm{~h}$. LDH activity was obtained by determining absorbance at $492-630 \mathrm{~nm}$ using a microplate reader. The cytotoxicity assay results were noted as the percent cytotoxicity according to the following formula:

$$
\text { Cytotoxicity }(\%)=\left[\frac{(\text { Experimental Value-Low Control) }}{\text { High Control-Low Control }} \times 100\right]
$$

\section{Cell imaging}

Cells were plated in 96-well plates at a density of 5.000 cells per well and allowed $24 \mathrm{~h}$. IC $_{50}$ values of the test compounds were administered and morphology alters of the cells were screened by phase contrast microscopy for $24 \mathrm{~h}$ every $6 \mathrm{~h}$. Images of control and test compounds treated cells were photographed at the end of the process using a digital camera attached to an inverted microscope.

\section{GC-MS analysis}

A Perkin Elmer Clarus 500 instrument with FID flame ionizing detector (Rtx-2330) and column ( $30 \mathrm{~m} \times 0.25 \mathrm{~mm} \times 0.2 \mu \mathrm{m}$ ) was used for fatty acid analysis. Methyl esters of 37 fatty acids were applied for standards. Temperature of the detector was $250^{\circ} \mathrm{C}$ and injection temperature was $250^{\circ} \mathrm{C}$. Injection splitting was $50 / 1$ and carriage gas flow was $1 \mathrm{~mL} / \mathrm{min}$.

\section{RESULTS and DISCUSSION}

\section{Antiproliferative effect of the Prunus laurocerasus extracts}

Here, different extracts of cherry laurel were conducted for their antiproliferative activity against cancer and normal cell lines using $5 \mathrm{FU}$ as a control anticancer drug. The medicines from natural sources such as plant, algae or fungi are used in the management and treatment of various diseases including cancer (15). For example, the fresh leaves of Prunus laurocerasus (British Pharmaceutical Codex, 1949) have been used as a flavoring agent (Cherry Pits, Extract (Prunus spp.)) in bad odor drugs and as a sedative for nausea or vomiting. With regard to the antiproliferative potential of cherry 
laurel, the data suggest that the growth of the cell lines was slightly inhibited by using cherry laurel extracts and among different extracts were not found any difference (Figure 1). The IC 50 values of cherry laurel extracts could not be calculated by using ELISA data. The data revealed that all cells were more durable than 5FU to cherry laurel extracts. Also, the proliferation of the cancerous cells of the cherry laurel extracts treatment was not statistically significant, compared with that of control cells ( $P>0.05$ ). It is known that natural products including various metabolites exhibit a strong pharmacological activity due to interact with cell type. Therefore, the antiproliferative activity of cherry laurel extracts mostly consisting of glycosides (amygdalin, prunasin, and sambunigrin) can be conducted using other type cell lines.

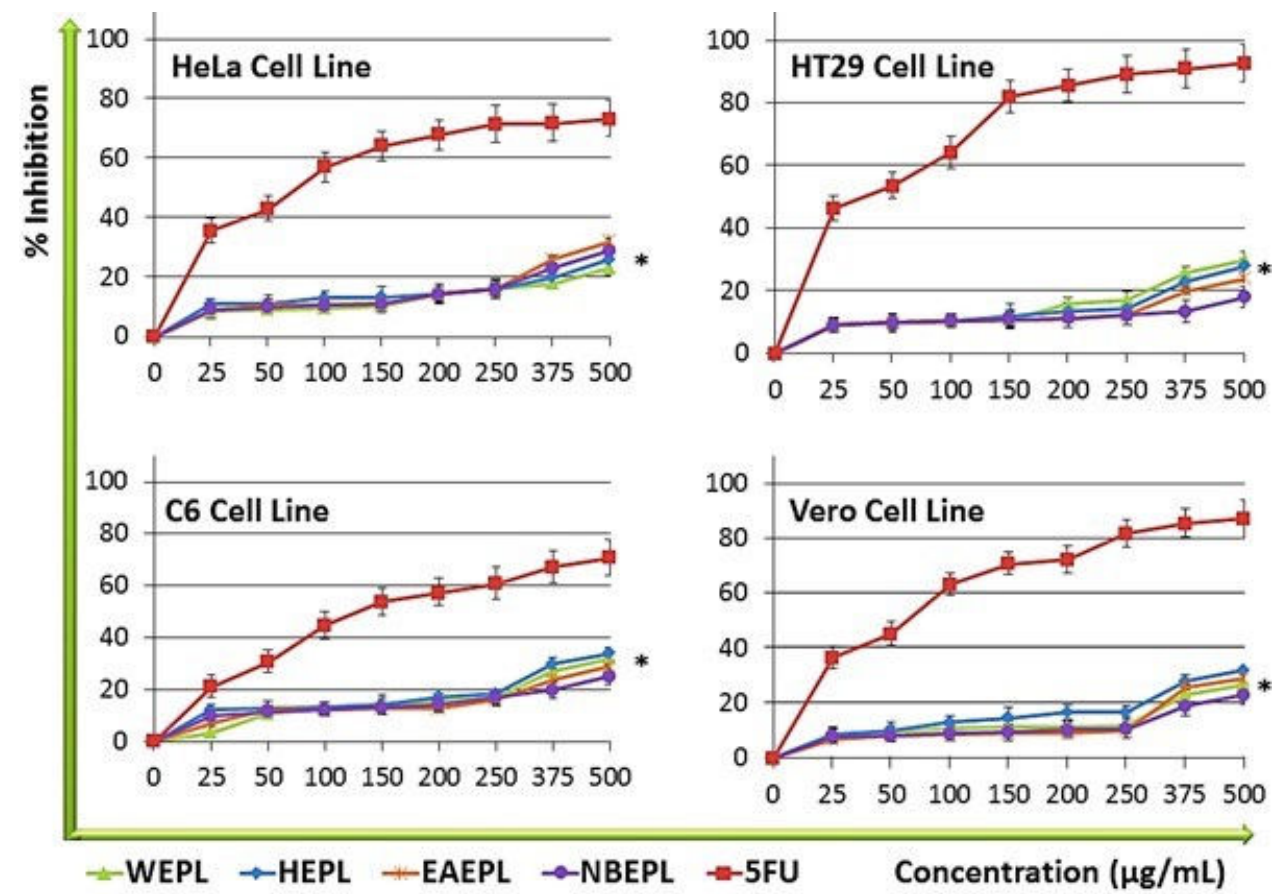

Figure 1. The Antiproliferative activity of cherry laurel extracts and positive control compound, 5FU on HeLa, HT29, C6, and Vero cell lines. Percent inhibition was noted as mean values \pm SEM of three independent assays $(P<0.05)$. Each experiment was repeated at least three times for each cell line. ${ }^{*} \mathrm{P}<0.05$ in comparison with the control.

\section{Cytotoxic activity of the Prunus laurocerasus extracts}

The cytotoxic activity of cherry laurel extracts on HeLa, HT29, C6, and Vero cell lines were tested using an LDH cytotoxicity assay kit and were determined by treating cells with varying concentrations of the cherry laurel extracts $(25,50,100,150,200,250$, 375 , and $500 \mu \mathrm{g} / \mathrm{mL}$ ), which showed concentration-dependent collapse of cell membrane. The findings of \% cytotoxicity delineate that treatment of cells with higher concentrations of cherry laurel extracts resulted in significant corruption of cell membrane integrity, but its low concentrations did not same effect on the cell membrane (Figure 2). The cell line showed no cytotoxic situations in response to cherry laurel extract treatment up to 375 
$\mu \mathrm{g} / \mathrm{mL}$, which confirms that cherry laurel extracts have no cytotoxicity in cells, but it exhibits slightly antiproliferative activity at $375 \mu \mathrm{g} / \mathrm{mL}$ and higher concentrations (Figure 2). Therefore, it is suggested that cherry laurel extracts may have a cytostatic potential towards the cells. Cherry Laurel contains flavonoids like kaempferol and quercetin, and caffeic and coumaric acid along with hydrocyanic acid. Quercetin is known to regulate the expression of apoptosis-related genes and to inhibit lymphocyte tyrosine kinase activity (16-18). Quercetin has also been shown to exhibit strong antiproliferative effects towards hepatocarcinoma in vivo experiments (19).

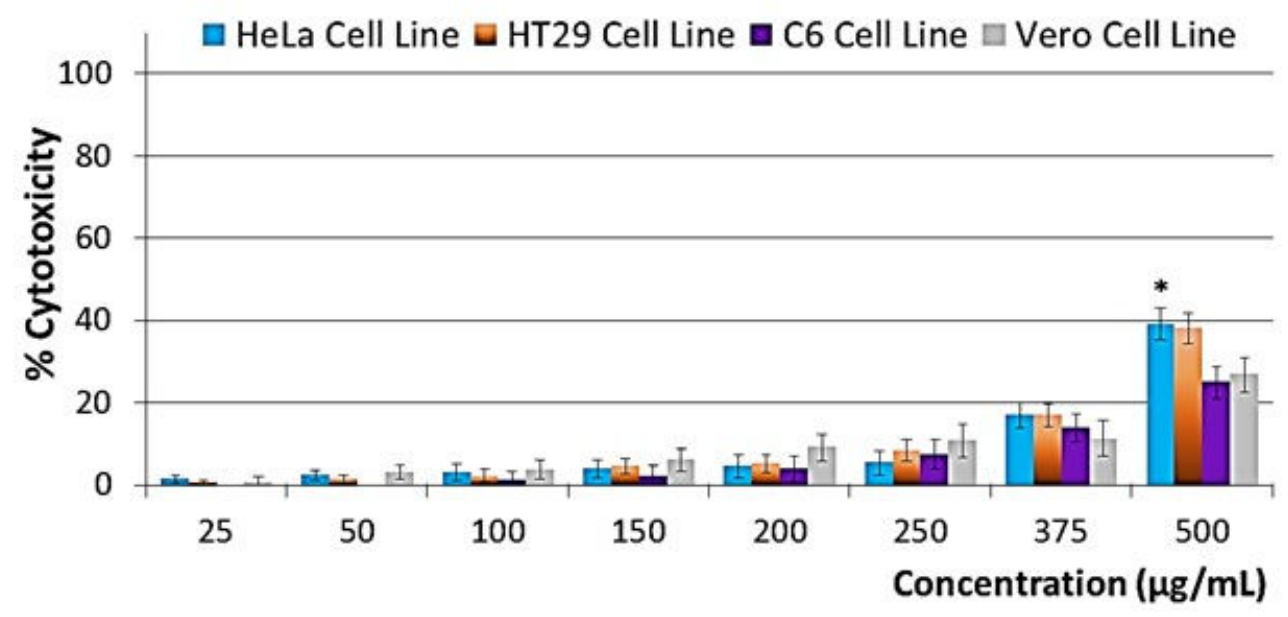

Figure 2. Cytotoxic activity of cherry laurel extracts on HeLa, HT29, C6, and Vero cell lines. Percent cytotoxicity was noted as mean values \pm SDs of three independent assays. $* \mathrm{P}<0.05$ in comparison with the control.

In a clinical trial, quercetin exhibited outstanding antitumor activity with safely i.v. usage (18). According to National Cancer Institute (20), however, laetrile (amygdalin) has displayed poor anticancer effect in animal experiments and no anticancer effect in clinical phase trials. Laetrile is not approved by FDA because of its side effects like hepatic damage, difficulty of walking, fever, coma, and death which are commonly dangerous. As demonstrated in above mentioned similar studies, cherry laurel extracts acting as an adjuvant agent in cancer treatment.

\section{Morphological assessment of the cytotoxic activity of the Prunus laurocerasus extracts}

The effect of the cherry laurel fruit extracts on the morphology of the cells were visualized by digital camera attached inverted microscope (Leica IL10, Germany). Picture shows inverted microscopic images of the morphology of treated cell lines with different concentrations of cherry laurel fruit extracts as compared to respective controls. The morphology of cherry laurel fruit extracts-treated cells at merely high concentration (>375 $\mu \mathrm{g} / \mathrm{mL}$ ) changed from a cell rounding to floating cells, an indication of cell death. The cherry laurel fruit extracts were not able to inhibit growth of the cells in the culture at low and medium dosages. The control groups displayed integrity confluent growth with 
normal proliferating cells. Similar to control cells, the majority of the treated cells was kept astrocyte-like or fibroblast-like appearance. Generally, at $375 \mu \mathrm{g} / \mathrm{mL}$ and higher doses, the numbers of cells seem to be less and separate from one another and they look small. Treatment with cherry laurel fruit extracts also delineated slightly degradations on the cells, as the cell growth affected and cellular morphology was similar to that of apoptotic situations only at high concentrations. However, the numbers of cells in low and medium concentrations of cherry laurel fruit extracts have not reduced and structurally, they look similar untreated cells.

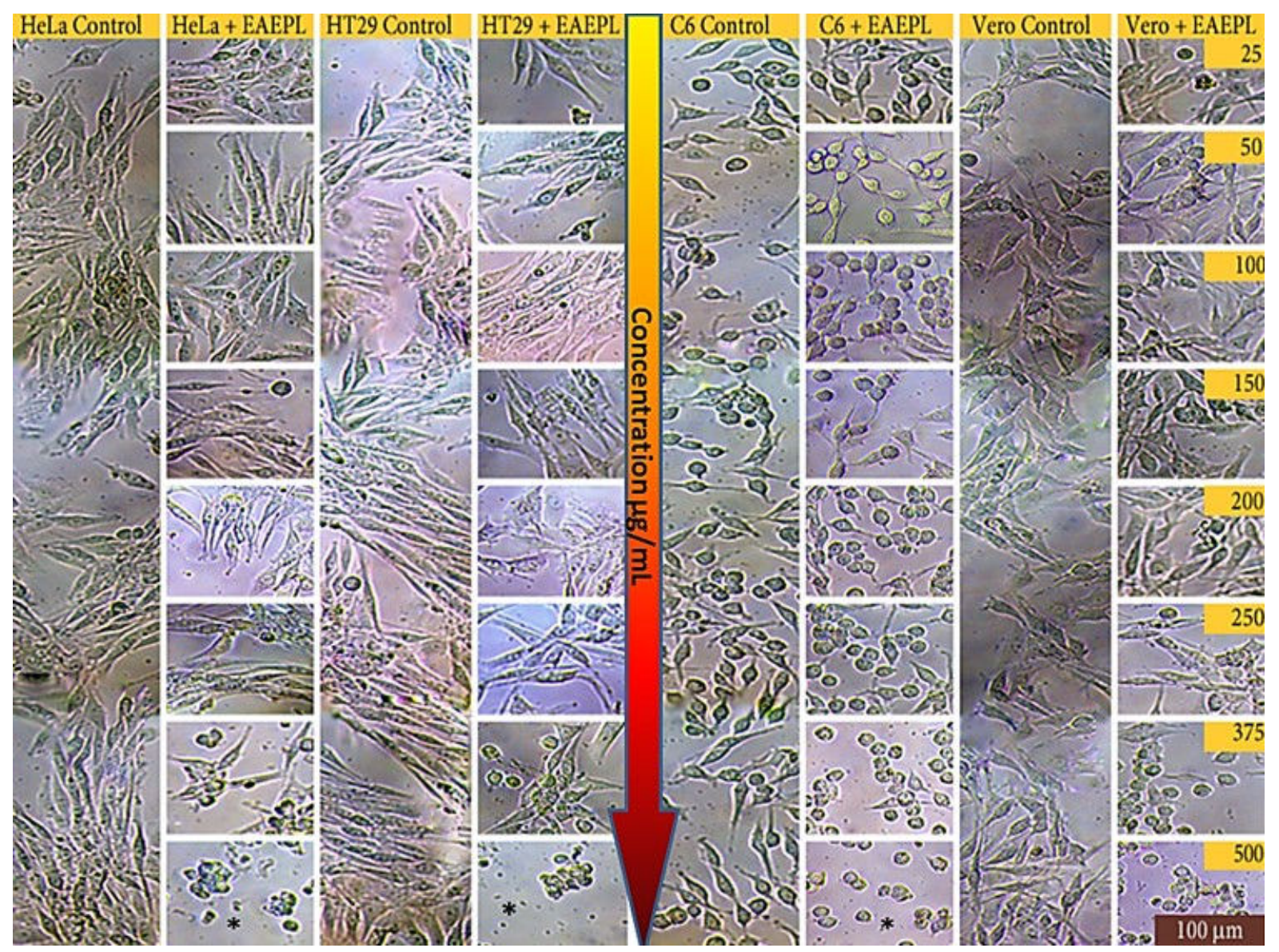

Figure 3. Effect of cherry laurel extracts on the morphology of HeLa, HT29, C6 and Vero cells. DMSO treated cells as controls. Asterisks point to the exposed surfaces from which cells have removed. All scales $100 \mu \mathrm{m}$.

\section{Fatty acid analysis}

Linoleic acid (18:2), palmitic acid (16:0) and oleic acid (18:1) were detected as fatty acids of hexane extract by GC-MS analysis. The human body cannot synthesize linoleic and oleic acids, both of which play an important role in the life. leading to regulate the blood homeostasis, the immune and inflammation response. In a similar study, main fatty acids constituents of cherry laurel were reported as linoleic, oleic, palmitic and stearic acid (21) which may be attributed to its pharmacological effects. Main ethereal 
Aydın, Erenler, Yılmaz, and Tekin, JOTCSA. 2016; 3(3): 217-228. RESEARCH ARTICLE

oils $(0.5 \%)$ of Cherry Laurel were noted as the benzaldehyde, benzyl alcohol, and hydrocyanic acid (22). Plant oil originated seed or fruit has been used as a healing agent for various diseases. The protective biological activity of cherry laurel extracts is possibly attributed to its high linoleic acid, palmitic acid, and oleic acid contents. It is speculated that these fatty acids may protect DNA, RNA and other macromolecules by modulating oxidative damage in cells (23). On the other hand, these fatty acids use their receptors such as G-protein receptors to exhibit its immunomodulatory effect. However, we should be considered that palmitic acid is generally cytotoxic to cells, whereas oleic acid and linoleic acid are cytoprotective in some certain concentrations in cells (23).

\section{CONCLUSION}

In this study, we have displayed biological effects of cherry laurel fruit extracts against HT29, HeLa, C6 and Vero cell lines. The fatty acid-rich bioactive components of cherry laurel fruit extracts that is responsible for the chemoprotective effect. We found that, cherry laurel fruit extracts exhibited considerable protective activity against cell lines at even the highest concentration. Overall, we speculate that cherry laurel fruit extracts could be an important natural source of adjuvant chemotherapeutic formulary.

\section{ACKNOWLEDGMENTS}

The authors thank the Gaziosmanpaşa University Research Foundation (Grant 2015/85) for financial support.

\section{AUTHOR CONTRIBUTIONS}

Conceived and designed the experiments: AA RE. Performed the experiments: AA BY. Analyzed the data: AA RE ŞT. Contributed reagents/materials/analysis tools: AA BY.

\section{REFERENCES}

1. Elgorashi E. Screening of medicinal plants used in South African traditional medicine for genotoxic effects. Toxicol. Lett. 2003; 143, 195-207. doi:10.1016/S0378-4274(03)001760

2. Sithranga Boopathy N, Kathiresan K. Anticancer Drugs from Marine Flora: An Overview. J. Oncol. 2010; 1-18. doi:10.1155/2010/214186

3. Lee CC, Houghton P. Cytotoxicity of plants from Malaysia and Thailand used traditionally to treat cancer. J. Ethnopharmacol. 2005; 100, 237-243. doi: 10.1016/j.jep.2005.01.064 
Aydın, Erenler, Yılmaz, and Tekin, JOTCSA. 2016; 3(3): 217-228. RESEARCH ARTICLE

4. Itharat $A$, Houghton $P J$, Eno-Amooquaye $E$, Burke $P$, Sampson $J H$, Raman $A$. In vitro cytotoxic activity of Thai medicinal plants used traditionally to treat cancer. J. Ethnopharmacol. 2004; 90, 33-38. doi: 10.1016/j.jep.2003.09.014

5. Elmastas M, Genc N, Demirtas I, Aksit H, Aboul-Enien HY. Isolation and Identification of Functional Components in Seed of Cherry Laurel (Laurocerasus officinalis Roem.) and Investigation of Their Antioxidant Capacity. J. Biol. Act. Prod. from Nat. 2013; 3, 115-120. doi: $10.1080 / 22311866.2013 .817736$

6. Karabegović IT, Stojičević SS, Veličković DT, Todorović ZB, Nikolić NČ, Lazić ML. The effect of different extraction techniques on the composition and antioxidant activity of cherry laurel (Prunus laurocerasus) leaf and fruit extracts. Ind. Crops Prod. 2014; 54, 142-148. doi: $10.1016 / j$.indcrop.2013.12.047

7. Türkan K, Kasim T, Bircan E, Murat K. DNA damage protecting activity and in vitro antioxidant potential of the methanol extract of Cherry (Prunus avium L). J. Med. Plants Res. 2014; 8, 715-726. doi:10.5897/JMPR2013.5350

8. Akkol EK, Kırmızıbekmez H, Kuçukboyacı N, Goren AC, Yesilada E. Isolation of active constituents from cherry laurel (Laurocerasus officinalis Roem.) leaves through bioassayguided procedures. J. Ethnopharmacol. 2012; 139, 527-532. doi: 10.1016/j.jep.2011.11.043

9. Alasalvar C, Al-Farsi M, Shahidi F. Compositional characteristics and antioxidant components of cherry laurel varieties and pekmez. J. Food Sci. 2005; 70(1), S47-S52. doi: 10.1111/j.1365-2621.2005.tb09064.x

10. Ayaz FA, Kadioglu A, Reunanen M, Var M. Phenolic acid and fatty acid composition in the fruits of Laurocerasus officinalis Roem. and its cultivars. J. Food Compos. Anal. 1997; 10(4), 350-357. doi:10.1006/jfca.1997.0550

11. Karahalil FY, Sahin H. Phenolic composition and antioxidant capacity of cherry laurel (Laurocerasus officinalis Roem.) sampled from Trabzon region, Turkey. Afr. J. Biotechnol. 2011; 10(72), 16293-16299. doi: 10.5897/AJB11.1929

12. Kolayli S, Kuçuk M, Duran C, Candan F, Dinçer B. Chemical and antioxidant properties of Laurocerasus officinalis Roem. (cherry laurel) fruit grown in the Black Sea region. J. Agric. Food Chem. 2003; 51(25), 7489-7494. doi: 10.1021/jf0344486

13. Sahan Y, Cansev A, Celik G, Cinar A. Determination of various chemical properties, total phenolic contents, antioxidant capacity and organic acids in Laurocerasus officinalis fruits. Acta Hortic. 2012; 939, 359-366. doi: 10.17660/ActaHortic.2012.939.47

14. Porstmann T, Ternynck T, Avrameas S. Quantitation of 5-bromo-2-deoxyuridine incorporation into DNA: an enzyme immunoassay for the assessment of the lymphoid cell proliferative response. J Immunol Methods 1985; 82, 169-79. doi:10.1016/0022-1759(85)90236-4.

15. Weerapreeyakul N, Nonpunya A, Barusrux S, Thitimetharoch T, Sripanidkulchai B. Evaluation of the anticancer potential of six herbs against a hepatoma cell line. Chin. Med. 2012; 7, 15. doi: $10.1186 / 1749-8546-7-15$

16. Zheng S-Y. Anticancer effect and apoptosis induction by quercetin in the human lung cancer cell line A-549. Mol. Med. Rep. 2011; 3, 822-6. doi: 10.3892/mmr.2011.726

17. Niu G, Yin S, Xie S, Li Y, Nie D, Ma L, Wang X, Wu Y. Quercetin induces apoptosis by activating caspase-3 and regulating Bcl-2 and cyclooxygenase-2 pathways in human HL-60 cells. Acta Biochim. Biophys. Sin. (Shanghai). 2011; 43, 30-37. doi: 10.1093/abbs/gmq107

18. Ferry DR, Smith A, Malkhandi J, Fyfe DW, DeTakats PG, Anderson D, Baker J, Kerr J. Phase I clinical trial of the flavonoid quercetin: pharmacokinetics and evidence for in vivo tyrosine kinase inhibition. Clin. Cancer Res. 1996; 2, 659-68. PMID: 9816216 
Aydın, Erenler, Yılmaz, and Tekin, JOTCSA. 2016; 3(3): 217-228. RESEARCH ARTICLE

19. Mandal AK, Das S, Mitra M, Chakrabarti RN, Chatterjee M, Das N. Vesicular flavonoid in combating diethylnitrosamine induced hepatocarcinoma in rat model. J Exp Ther Oncol 2008; 7, 123-133. PMID: 18771086

20. C.T.E.B.PDQ Integrative, Alternative, Laetrile/Amygdalin (PDQ®): Health Professional Version. 2002.

21. Halilova H, Ercisli S. Several Physico-Chemical Characteristics of Cherry Laurel (Laurocerasos Officinalis Roem.) Fruits. Biotechnol. Biotechnol. Equip. 2010; 24, 1970-1973. doi: 10.2478/V10133-010-0059-6

22. Stanisavljević IT, Lazić ML, Veljković VB, Stojičević SS, Veličković DT, Ristić MS. Kinetics of Hydrodistillation and Chemical Composition of Essential Oil from Cherry Laurel (Prunus laurocerasus L. var. serbica Pančić) Leaves. J. Essent. Oil Res. 2010; 22, 564-567. doi: $10.1080 / 10412905.2010 .9700401$

23. Herbal medicine: biomolecular and clinical aspects / editors, Iris F.F. Benzie and Sissi WachtelGalor. 2nd ed. Boca Raton: FL 33487-2742, CRC Press/Taylor \& Francis Group; 2011. ISBN: 978-1-4398-0713-2. 
Aydın, Erenler, Yılmaz, and Tekin, JOTCSA. 2016; 3(3): 217-228. RESEARCH ARTICLE

Türkçe Öz ve Anahtar Kelimeler

Taflan Ağacının Antiproliferatif Etkisi

Ali Aydın, Ramazan Erenler, Bülent Yılmaz, Şaban Tekin

Öz: Taflan ağacı (Prunus laurocerasus) meyveleri fenolik ve flavonoid içerikler barındırmakta olup taze, kurutulmuş veya marmelat şeklinde tüketilirken yaprakları siyanojenik glikozidler içerir ve Anadolu folklorik tıbbında iyi bilinen iyileştirici etkilere sahiptir. Burada, taflan ağacı meyveleri suda 2 saat kaynatılmış, heksan, EtOAc ve BuOH ile ayrı ayrı ekstrakte edilmiştir. Ekstraktların antiproliferatif etkisi HeLa (İnsan Rahim Boynu Kanseri), HT29 (İnsan Kolorektal Adenokarsinoma), C6 (Sıçan Beyin Tümör Hücreleri) ve Vero (Afrika Yeşil Maymun Böbreği) hücre çizgileri üzerinde incelenmiştir. Bütün ekstraktlar yüksek derişimde çeşitli kanser hücre çizgilerinde hafif antiproliferatif etki göstermiştir. Taflan ağacı meyvesinin ekstraktlarının hücre zarını parçalama yeteneğini değerlendirdik. Sonuçlara göre taflan ağacı meyvesi sadece yüksek derişimlerde tümör hücre çizgilerinde hücre zarını biraz parçaladığı görülmektedir. Bu çalışmanın sonuçları taflan ağacı meyvesinin ekstraktlarının kanser hücreleri için antikanser araç olarak etkinliğini desteklememektedir, ancak şu andaki kemoterapötik araçlara potansiyel destek tedavisi yaparak hücre zehirliliğini düşürecek şekilde kullanılabieceğini göstermektedir. Heksan ekstraktında GC-MS analizi ile yağ asitleri bulunmuştur ve ana ürünler linoleik asit, palmitik asit ve oleik asit içermektedir.

Anahtar kelimeler: Taflan ağacı,, Laetrile, Antikanser aktivitesi, Sitotoksik aktivite. 
Aydın, Erenler, Yılmaz, and Tekin, JOTCSA. 2016; 3(3): 217-228. RESEARCH ARTICLE 